\title{
The Old Ammunition Store of the Ereta and the Luceros-Marq Railway Tunnel of the TRAM in Alicante. Radon gas measurement
}

\author{
Carlos Rizo Maestre ${ }^{1}$, Armando Ortuño Padilla ${ }^{2}$, Servando Chinchón Yepes ${ }^{3}$ \\ ${ }^{1}$ Architect, University Institute of Water and Environmental Sciences, EDUA, Alicante University. Alicante, Spain \\ ${ }^{2}$ Professor, University Institute of Water and Environmental Sciences, EDUA, Alicante University. Alicante, Spain \\ ${ }^{3}$ Professor, Architectural Constructions Department, Alicante University. Alicante, Spain
}

\begin{abstract}
The study presented analyzes the amount of Radon gas in two unique constructions of the city of Alicante: The Old Ammunition Store of the Ereta ("Polvorin de la Ereta") and the Luceros-Marq Railway Tunnel of the TRAM in Alicante (Spain). These infrastructures are very important for the city due to its historical character in the case of the magazine, or its social importance in the case of the Railway Tunnel. The presence of Radon gas in buildings is an indicator of air quality. This radioactive gaseous element is present in almost all the building materials, and in the lands in which the buildings are implanted. In Spain, the Technical Building Code (TBC) does not yet contemplate the maximum dose of Radon that one building can house and how to contain it. Radon gas is considered to be highly harmful to human beings by different scientific agencies in the field of medicine and health, including the World Health Organization (WHO). The main effect of the presence of Radon in the human environment is the risk of lung cancer.
\end{abstract}

Keywords: Radon, Healthy Architecture, Materials

\section{INTRODUCTION}

Radioactivity is a physical phenomenon by which the unstable isotopes of certain chemical elements are able to lose energy and become other more stable isotopes. The process involves the emission of radiation in the form of electromagnetic waves (Xrays and gamma rays) or particles (alpha, beta and neutrons).

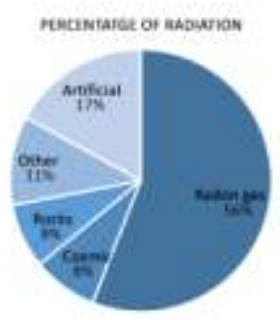

Fig. 1: Percentage of radioactivity in the environment

This type of radiation is called ionizing because when it penetrates matter, it usually pulls electrons from the surrounding atoms by a process known as ionization. If the material is biological tissue with a high-water content, the ionization of water molecules can give rise to so-called free radicals that have a high chemical reactivity, sufficient to alter important molecules that are part of the tissues of living beings. These alterations may include chemical changes in DNA, the basic organic molecule that is part of the cells that make up our body [1]. These changes can lead to the appearance of biological effects, including the abnormal development of cells [2]. These alterations can be more or less severe depending on the dose of radiation received [3].

Three quarters of the radioactivity in the environment comes from the natural elements. In this sense, radon is the major source of natural radioactivity (Fig. 1) and the public health problem generated by its concentration and that of its descendants in drinking water or in the interior of the buildings has made people aware of that what has hitherto been considered a despicable fund has, at least, to be determined for its correct evaluation [4].

Radon gas is produced as a result of the disintegration of uranium and thorium contained in the rocks. The amount of this gas that accumulates in a building depends on its situation, the materials that have been used in its construction and our way of life (ventilation and time in a stay). Radon emanates from rocks and concentrates in enclosed places, so it is highly recommended that homes and workplaces are properly ventilated [5].

Radon concentrations in a building vary substantially with the geographical location. Given the large number of factors involved, it is very difficult to predict whether the levels of this gas will be raised in a particular dwelling; on the other hand, it is possible to make reliable predictions about the areas where there is a greater probability of finding houses with high concentrations.

\section{Measurement of Radon gas on Benacantil MOUNT}

This study presents the results of the Radon gas content in one of the most important geographical points of the city of Alicante: Benacantil Mount, 
where the elements of the study are located, the Polvorín de la Ereta and the Luceros-Marq railway tunnel (Fig. 2).

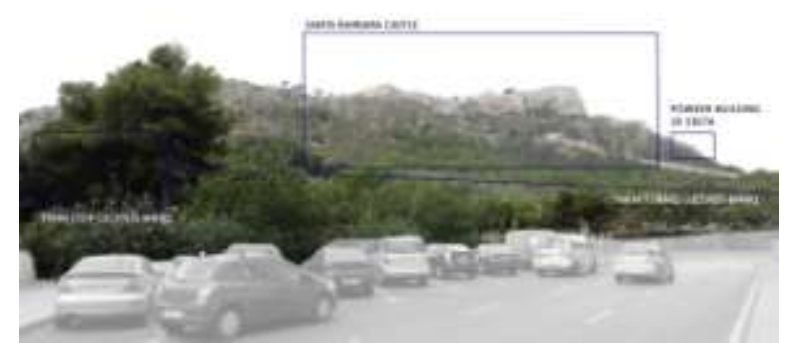

Fig. 2: Image of the west side of Benacantil Mount where the situation of the two constructions studied can be seen

The measurement of radon gas in these two dependencies of Benacantil Mount is interesting because of its different typology, both temporal and constructive. The city of Alicante is in a lithological zone with low presence of uranium and thorium, which are the two gas formation chains, is considered of low potential in gas content Radon according to the predictive map MARNA of gas content Radon in Spain [6].

The Benacantil Mount, by its position, is the most important point of the urban nucleus of Alicante, being in a privileged zone for its proximity to the sea and to have a height of approximately 166 meters where the Castle of Santa Barbara is located, being this the construction of the urban center. On the south side of the castle is the Polvorín de la Ereta, a building used to guard the city's army weapons. The Train Tunnel of the Metropolitan Transport of Alicante (TRAM) passing through the slopes of Benacantil Mount, is a modern construction of the XXI century, which serves to connect the hull of the city of Alicante with the north.

Benacantil Mount is located next to the shore of the Mediterranean Sea and is adapted for the ascent of both pedestrians and vehicles. The usual way to get to the top of the mountain is through the promontory located on the Avenida de Dénia (urban crossing of the $\mathrm{CN}-332$ road). With a lift that saves the existing $142 \mathrm{~m}$ difference from Postiguet Beach and reaches the castle, at the top of the hill. Road traffic accesses from Avenida Jaime II, extension of Avenida Alfonso $\mathrm{X}$ el Sabio, through which runs the Rail Tunnel of Luceros-Marq.

\section{The POLVORÍN DE LA ERETA}

In the south slope of Benacantil Mount there is a nave of the nineteenth century well known by the Alicante population given its privileged location, but with little written historical route that shows the importance of this construction within history. The information regarding this building is very scarce due to the passage of the years and the atypical of the place. For this reason, we thank the collaboration of Pablo Rosser, current head of the Historical Memory Section of the city of Alicante and writer of the book "Origin and evolution of the walls of Alicante," which cites the quotes of different authors of this building [7]

As shown in Fig. 3 the magazine is a rectangular building of a single height, with the arc-shaped roof creating a slight slope. This construction has a great thickness of approximately one meter in all its sides due to its defensive identity, reinforced with reinforced concrete to resist the fall of bombs. Fig. 3 shows the surroundings of the building with the Parque de la Ereta, an element that connects the Barrio de la Santa Cruz with the Santa Bárbara Castle.

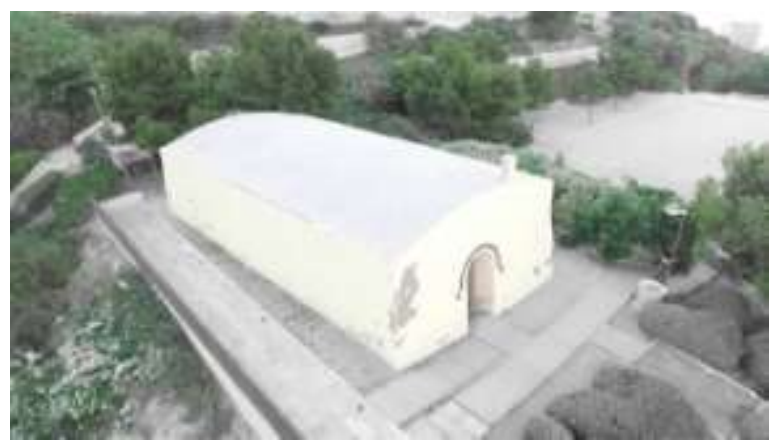

Fig. 3: Image of the Polvorín de la Ereta made with dron at a height of 20 meters above the ground level

\section{THE LUCEROS-MARQ RAILWAY TUNNEL}

The Luceros-Marq Railway Tunnel is next to that of the Serra Grossa one of the most important civil works carried out in the 21 st century in the city of Alicante. This infrastructure links Marq-Castillo stations, to the slopes of Benacantil Mount, with the station of Luceros, although in the future its pretensions are to reach the railway station of Renfe itself and serve as a connection to the city with travelers arriving from all Spain. The route of the tunnel passes under the avenues of Alfonso X el Sabio, the Station and Jaime II until entering the Benacantil Mount (Fig 4), reaching fifteen meters below the zero level of the street.

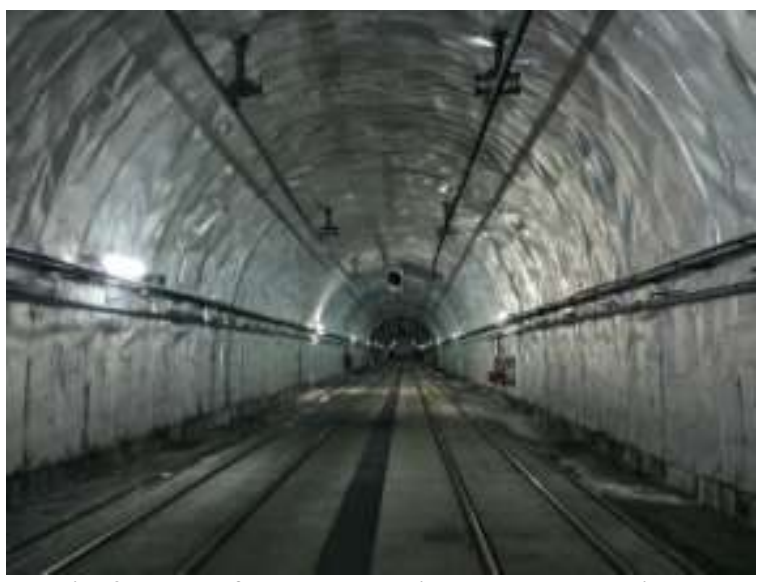

Fig. 4: Image of the tunnel during the data collection phase. The image corresponds to the tunnel as it passes through the Benacantil Mount 


\section{MeThodologY}

The study of the air quality carried out in the two dependencies of Benacantil Mount with the Radon gas as an indicator was performed using an Electrete Ionic Chamber Meter (EICM), a system that combines a camera with a device that works at the same time as generator of an electric field and sensor. Fig. 5 shows the elements used in each of the zones measured in the study.

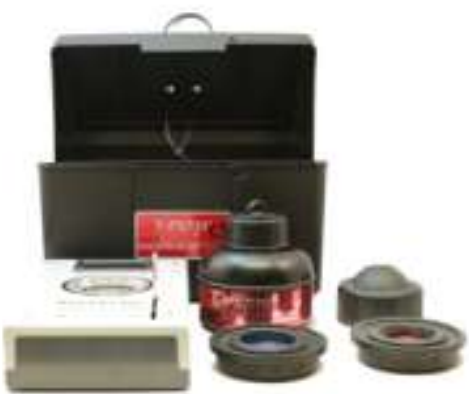

Fig. 5: Image showing the equipment used during the study, the elements that compose it are the meter, a tamper-resistant case, a short-time camera, a long-time camera, a short (blue) and a long (red) electret.

Sampling of the amount of Radon gas was started on December 2015 and had a different duration for each of the selected sites, and was completed on July 2016. For the choice of measurement sites, two Basic premises: closed rooms with little ventilation and the possibility of remaining without traffic of people during the days of measurement. The deposit of the elements had to be adapted to the needs of the places and their custodians.

The two constructive elements studied (Polvorín de la Ereta and Luceros-Marq Railway Tunnel) have very different ventilation and use conditions, each using the appropriate measuring method within the Electrete Ionic Chamber system. The places chosen for each of the places and how to use the equipment were previously analyzed, establishing the type of camera and electrete (short or long time) more appropriate in each case according to the possibilities of time available and the use of the installation.

Fig. 6 shows the arrangement of the measuring chambers inside the Polvorín de la Ereta, of a single room, the different areas of the room were taken into account to establish a parallel study of the different air renovation within the same room. Fig. 7 shows the arrangement of the chambers within the studied tunnel, for which special attention was given to the movement of trains and mechanical elements by the renovation of air produced inside the tunnel.

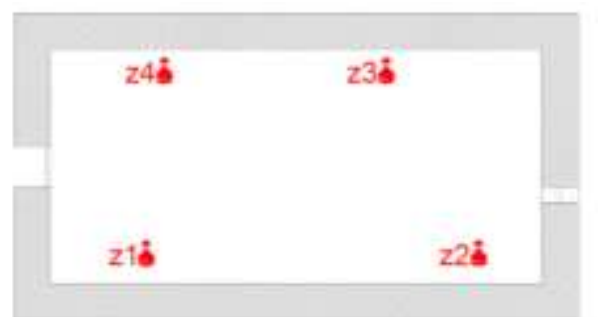

Fig. 6: Image of the plant with the arrangement of the measurements made in the study. The Polvorín is an architectural element 12 meters long and 4 meters wide

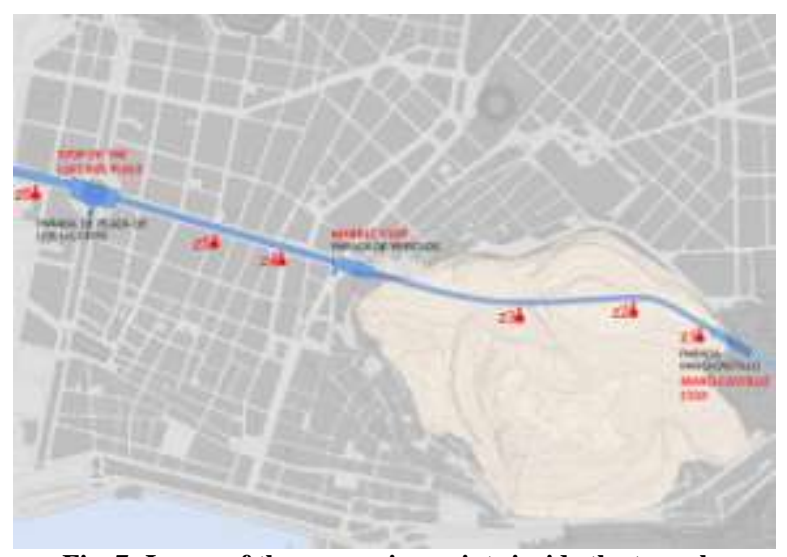

Fig. 7: Image of the measuring points inside the tunnel on a plane of the city of Alicante where Benacantil Mount stands out

\section{VI.RESULTS}

The results obtained in the different phases of data collection have been expressed for this article by making a mean among all the samples obtained in each of the places.

The data collection phase inside the Polvorín de la Ereta was carried out in four places of the same room, depositing two cameras in each one of them to verify that there were no deviations. This part of the study was very interesting for further verification because of the different accumulation of Radon gas in the same closed room according to the zone [8]. The results obtained are shown in Table 1.

The results obtained from the amount of Radon gas inside the tunnel were low (Table 2); The large air extraction equipment placed together with the movement of the trains coming from outside, make the air is continuously renewed which entails the low presence of Radon gas.

Table 1. Summary measurements Polvorín de la Ereta

\begin{tabular}{|l|l|c|c|}
\hline \multicolumn{2}{|c|}{ Place } & Samples & Radón medio $\left(\mathrm{Bq} / \mathrm{m}^{3}\right)$ \\
\hline Zone 1 & Location 1 & 2 & 121,32 \\
\hline Zone 2 & Location 2 & 2 & 126,45 \\
\hline Zone 3 & Location 3 & 2 & 241,89 \\
\hline Zone 4 & Location 4 & 2 & 243,45 \\
\hline
\end{tabular}

Table 2. Summary measurements Tunnel Luceros-Marq

\begin{tabular}{|c|c|c|c|}
\hline \multicolumn{2}{|c|}{ Place } & Samples & Radón medio $\left(\mathrm{Bq} / \mathrm{m}^{3}\right)$ \\
\hline Zone 1 & 65m Marq & 1 & 19,08 \\
\hline Zone 2 & $\begin{array}{c}\text { 155m Marq, 610m } \\
\text { Mercado }\end{array}$ & 2 & 12,63 \\
\hline Zone 3 & $\begin{array}{c}\text { 424m Marq, 340m } \\
\text { Mercado }\end{array}$ & 6 & 75,99 \\
\hline
\end{tabular}




\begin{tabular}{|c|c|c|c|}
\hline \multicolumn{2}{|c|}{ Place } & Samples & Radón medio $\left(\mathrm{Bq} / \mathrm{m}^{3}\right)$ \\
\hline Zone 4 & $\begin{array}{c}\text { 105m Mercado, 420m } \\
\text { Luceros }\end{array}$ & 2 & 27,88 \\
\hline Zone 5 & $\begin{array}{c}\text { 265m Mercado, 270m } \\
\text { Luceros }\end{array}$ & 3 & 20,53 \\
\hline Zone 6 & $\begin{array}{c}\text { 66m Luceros, dirección } \\
\text { Renfe }\end{array}$ & 2 & 182,00 \\
\hline \multicolumn{2}{|c|}{} \\
\hline
\end{tabular}

\section{DISCUSSION OF RESULTS}

The results obtained in the different measurements are compared with the $400 \mathrm{~Bq} / \mathrm{m}^{3}$ dose, recommended not to exceed in 1990 by the European Commission for Atomic Energy [9] and the $100 \mathrm{~Bq} / \mathrm{m}^{3}$ of exposure to residential Radon which was recommended by the WHO [10]. At present, the incidence of Radon gas in human beings is still being studied, in order to establish gas values and under what conditions improvement measures must be taken. In order to extract the results of the study, the two previously mentioned values are evaluated, considering those less than $100 \mathrm{~Bq} / \mathrm{m}^{3}$ as normal, between 100 and 400 $\mathrm{Bq} / \mathrm{m}^{3}$ to be taken into account, and those higher than $400 \mathrm{~Bq} / \mathrm{m}^{3}$ as places in which action should be taken [11].

In the Luceros-Marq Railway Tunnel, in the six zones that were studied during the eight days that the measurement was carried out, all values were much lower than those that could be considered susceptible to solve. The only place that turned out to have somewhat high values, with an average of $182 \mathrm{~Bq} / \mathrm{m}^{3}$, was the section of the tunnel linking the current stop of Luceros with the future Renfe stop (Zone 6). This section is in disuse since the trains do not circulate and the air extraction systems are not connected, being the amount of renewed air smaller. In the future, when connected to the Renfe stop, train traffic and the ventilation measures themselves are likely to improve the accumulated Radon gas values.

In view of the results presented in this work, the need and compliance of ventilation measures to contain the presence of Radon gas in buildings, especially in closed spaces used by people, is verified. As it is reflected in the Technical Report 38.2013 of the Nuclear Safety Council [11], radiological studies on exposures to radon in underground work and leisure places should be compulsory (Including public car parks, mines, metro, museums, tourist caves, etc.). All this regardless of the type of rock on which buildings settle and the type of materials used.

Radon gas is harmful to human health, becoming a highly carcinogenic element and therefore, the new construction regulations are working on incorporating this point as a control element. The largest source of this gas is the land, with buildings with low protection measures or underground being able to accumulate larger amounts of this gas. The new constructive forms make the buildings more and more hermetic and prevent the air renewal. Other factors to take into account are the extreme temperatures, since they facilitate the accumulation of the gas by the pressure difference and the precipitations that facilitate the ionization of places.

The Polvorín de la Ereta, despite being a construction in contact with the land, does not accumulate large amounts of Radon gas inside and therefore no improvement measures should be taken.

The Luceros-Marq Tunnel, which passes through the slopes of Benacantil Mount, has a high air renewal rate in its interior produced both by the movement of trains and by the extraction systems, thus the accumulation of Radon gas in its interior is low.

The line of work in which this article is framed reinforces the need to incorporate protocols and standards for radon control into the Spanish building regulations.

\section{ACKNOWLEDGMENTS}

The author of this study thank the University of Alicante and the people who have facilitated the different stages of the research. This article is part of the Doctoral Thesis of Carlos Rizo Maestre, which thanks the University Institute of Water and Environmental Sciences the possibility of having carried out this Project.

\section{REFERENCES}

[1] United Nations. Scientific Committee on the Effects of Atomic Radiation., Sources and effects of ionizing radiation $\square$ : United Nations Scientific Committee on the Effects of Atomic Radiation $\square$ : UNSCEAR 2000 report to the General Assembly, with scientific annexes. United Nations, 2000.

[2] R. Barbosa-Lorenzo, A. Ruano-Ravina, S. Cerdeira Caramés, and J. M. Barros-Dios, "Radón residencial y cáncer de pulmón. Un estudio ecológico en Galicia," Med. Clin. (Barc)., vol. 144, no. 7, pp. 304-308, Apr. 2015.

[3] Consejo de Seguridad Nuclear, Dosis de Radiación. Editor Consejo de Seguridad Nuclear, 2010.

[4] J. L. Llerena Cristobo, Medición de la concentración de gas $222 R n$ en el interior de edificios. USC. Departamento de Física de las Partículas, 2006.

[5] M. Olaya and F. Borja, "El Código Técnico de la Edificación en España (CTE) Medidas correctoras destinadas a frenar la entrada de radón en los edificios. Investigación de campo como experiencia piloto en España," 2007.

[6] E. Suarez Mahou, J. Á. Fernández Amigot, A. Baeza Espasa, M. C. Moro Bonito, J. Moreno del Pozo, and J. M. Lanaja del Busto, Proyecto Marna (Mapa de radiación gamma natural en España). Editor Consejo de Seguridad Nuclear, 2000.

[7] P. Rosser Limiñana, Origen y evolución de las murallas de Alicante. Editor V Centenario de la Ciudad de Alicante, 1990.

[8] G. Mentes and I. Eper-Pápai, "Investigation of temperature and barometric pressure variation effects on radon concentration in the Sopronbánfalva Geodynamic Observatory, Hungary," J. Environ. Radioact., vol. 149, pp. 64-72, 2015.

[9] 90/143/EURATOM, "Recomendación de la comisión EURATOM, de 21 de febrero de 1990, relativa a la protección de la población contra los peligros de una exposición al radón en el interior de edificios," 1990.

[10] H. Zeeb, F. Shannoun, and W. H. Organization, "WHO handbook on indoor radon: a public health perspective," 2009.

[11] M. García-Talavera San Miguel, J. L. Martín Matarranz, R. Gil de Mingo, J. P. García Cadierno, and E. Suárez Mahou, El mapa predictivo de exposición al radón en España. Editor Consejo de Seguridad Nuclear, 2013. 